\title{
A Study on the Countermeasures of Strengthening the Construction of Teachers in Colleges and Universities
}

\author{
LiJingHan ${ }^{1, \mathrm{a}}$
}

\author{
${ }^{1}$ School of Music and Dance, Zhuhai College, Jilin University, Guangdong, China \\ a2398996211@qq.com
}

\begin{abstract}
Since the 18th National Congress of the Party, the CPC Central Committee with Comrade Xi Jinping as the core has attached great importance to education, put forward a series of innovative new ideas and new ideas around the fundamental question of "who to train, how to train, and who to train ", and systematically answered a series of major questions of directionality, overall nature and strategy, which provided fundamental compliance for the development of education. Through combing the literature related to the construction of college teachers, this paper summarizes the main measures and achievements of the construction of college teachers in the aspects of talent introduction, implementation of "three major projects ", independent evaluation of professional titles, optimization of team structure, and points out some young teachers in colleges and universities. The difficulties and reasons in teaching and scientific research experience, professional title evaluation, university's own platform resources, government investment funds, teachers' professional identity, mobility and so on are put forward. Finally, the countermeasures taken by colleges and universities to strengthen the construction of rules and regulations, cadres, comprehensive management and so on are put forward.
\end{abstract}

Keywords: university; faculty; education; countermeasure

\section{高校加强师资队伍建设的对策研究}

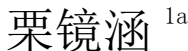

${ }^{1}$ 吉林大学珠海学院音乐舞蹈学院, 珠海, 广东, 中国

${ }^{1}$ School of Music and Dance, Zhuhai College, Jilin University, Guangdong, China

a2398996211@qq.com

\section{摘要}

党的十八大以来, 以习近平同志为核心的党中央高度重视教育工作，围绕 “培养什么人、怎样培养人、 为谁培养人” 这一根本问题提出一系列富有创见的新理念新思想新观点, 系统回答了一系列方向性、 全局性、战略性重大问题, 为教育事业发展提供了根本遵循。通过梳理高校师资队伍建设相关的文献, 总结了高校师资队伍建设在人才引进、实施 “三大工程”、职称自主评审、队伍结构优化等方面的主要 举措及成效，指出了有些高校青年教师教学和科研经历、职称评审、高校自身平台资源、政府投入资 金、教师的职业认同感、流动性等方面存在的困难和原因，最后提出了高校加强师资队伍建设在规章 制度、干部队伍、综合管理等方面采取的对策。

关键词：高校；师资队伍；教育；对策

\section{1. 前言}

习近平总书记在 2018 年 9 月召开的全国教育大会
上提出 “教育是国之大计、党之大计” 的重要论断。 ${ }^{[1]}$ 这一重要论断把教育摆在了前所未有的战略地位, 把教 育与国家的前途命运、党的前途命运紧紧联系在一起, 丰富和发展了中国特色社会主义教育理论, 是做好新时 代教育工作的行动指南。共产党人不忘初心、牢记使命, 
为实现 “两个一百年” 奋斗目标和中华民族伟大复兴的 中国梦做出突出贡献, 归根到底要靠人才、靠教育。教 育大计, 教师为本。努力建设一支师德师风优良、结构 合理、精干高效、充满生机活力的高校师资队伍，是提 高高校办学质量的必要条件。

\section{2. 高校师资队伍建设方面的主要举措及成效}

一直以来，高校都高度重视师资队伍的规划和建设, 牢固树立教师是办学主体的理念, 把师资队伍建设作为 提高人才培养质量的根本保证, 加强师德教育, 通过 “引 育并举”, 大力推进 “三大工程” 即 “百人工程” 青年 教师培养计划、“三个层次” 师资骨干队伍建设计划和 博士提升计划等培养项目, 打造多途径平台加强师资培 训, 特别是青年教师的培养工作, 师资队伍整体素质明 显提高。

\section{1 拓宽师资来源，人才引进初见成效}

高校树立 “不求所有, 但求所用” 的用人观念, 采 用 “柔性引进” 模式, 走专兼职教师相结合的道路, 提 高人才使用效益, 增强对复杂多变形势的应对能力。积 极引进有影响的学科带头人、青年博士、教学经验丰富 的返聘教师、实践经验丰富的 “双师双能型” 教师。近 年来, 各高校引进自有专任教师, 大部分都是教授, 副 教授, 博士等级别的人才。此外, 有些高校还采取多种 方式加强兼职教师队伍建设, 建立了优质的兼职教师资 源库, 一批国家级、省部级高层次人才受聘为高校特聘 教授, 一批知名科研机构、企事业单位的企业家、艺术 家、高级技术人员受聘为高校长期兼职教师, 承担相关 教学科研、实习实训指导以及团队建设等任务。

\section{2 多措并举，青年教师快速成长}

高校立足于青年教师的专业发展, 积极开展青年教 师 “校本培养”, 强调教师队伍职业化、专业化建设。 围绕 “培养什么人、怎样培养人、为谁培养人” 这一根 本问题, 全面加强党对教育工作的领导。在青年教师的 成长中, 更要加强职业伦理培养, 促进青年教师顺利成 长。 ${ }^{[2]}$ 坚持立德树人, 高校每年都开展师德和学风建设 主题月活动, 努力构建师德、学风建设的长效机制。高 校人事部门和教师教学发展中心对新进教师、在职教师 和研究生助教实施教师教学能力发展系列提升计划, 进 行教学评价与评奖, 鼓励、引导、帮助教师提升教学能 力与水平。高校实行 “导师负责制”, 聘请校内教学经 验丰富的优秀教师对新进青年教师进行“一对一”或“一 对二” 指导。高校鼓励教师在职培训进修, 鼓励教师在 职攻读博士学位, 多名教师到部门挂职锻炼。高校每年 还选派一些教师出国 (境) 考察和访问, 扩大教师视野, 了解国外教育现状。

\section{3 实施 “三大工程”，建设高水平教师队伍}

高校意识到, 建设高水平的教师队伍, 必须提高教 师队伍的总体素质和专业化水平。为提高青年教师科研 能力, 高校实施 “百人工程” 青年教师培养计划, 为引 进及培养一批高水平的骨干教师, 实施 “三个层次” 师资骨干队伍建设计划, 全力打造一支中青年学科、学 术带头人、专业骨干和教学科研并重型教师组成的师资 骨干力量。每年高校都遴选 “三个层次” 骨干教师，有 些教师入选第一层次一学科（术）带头人，有些教师入 选第二层次一专业骨干教师，还有些教师入选第三层次 一教学科研并重型教师。为激励具有博士学位的教师在 教学、科研和学科建设中发挥更大的作用, 有些高校实 施了博士提升计划。“三大工程” 的实施, 不仅壮大了 高校的师资力量, 更推动了学术、科研的快速发展。

\section{4 落实放管服改革精神，做好职称自主评审 工作}

高校职称评审权下放是高等教育领域的一项重大 改革, 其目的就是更好发挥职称评价“指挥棒”的作用。 高校高度重视职称改革工作, 力争充分发挥本次改革的 作用。各高校按照不低于省职称评审条件的原则, 结合 高校的实际情况, 经过人事、教学、科研等部门反复研 究, 广泛征求教职工以及学术委员会各学科专家的意见, 高校制定了职称评聘办法, 经高校教代会和职称评聘领 导小组审议通过后, 报省人社厅和省教育厅备案通过。

有些高校已经顺利开展了教师职称评审工作，并根 据评聘结合的原则予以聘任。该工作涉及到教师的切身 利益, 是教师关注的焦点, 高校从组织职称文件的制定 开始，到上报备案、以及到整个评审工作的实施过程, 如工作布置、组织申报、材料审核、双公示、相关异议 的处理、评委的抽取、评审会议等各环节均不折不扣的 按照文件规定的流程操作, 确保了职称评审工作有序稳 妥地圆满完成, 达到了预期效果, 评审结果未有异议。 目前在职称评审指挥棒的作用下, 高校教职工工作积极 性明显提高, 特别是参与科研的积极性有了很大的提高, 有效地促进了高校的教学科研等工作的开展。

\section{5师资队伍结构不断优化，建设成效显著}

近几年，通过一系列师资队伍建设举措，高校师资 队伍的职称学历结构不断优化, 高级职称教师比例明显 提升, 教师教学科研能力显著增强, 教学科研业绩成果 丰硕。高校教师整体素质提升明显, 在参加有关教师授 课比赛等评选活动中屡获殊荣, 其中高校优秀教师、高 校师德先进个人、高校三八红旗手、高校教学名师、高 校教育优秀教育工作者等评选活动, 极大的激发了高校 教师为教育奉献的热情。高校积极推进教师入选国家公 派出国留学地方合作项目, 越来越多的高校教师入选高 校优秀青年教师培养计划，入选高校 “千百十人才培养 
工程”培养计划，很多教师获得高校中青年教师国内访 问学者项目资助。

\section{3. 高校师资队伍建设方面存在的主要困难和 原因}

刚入职的青年教师大部分是刚毕业的大学生, 有些 青年教师在入职前缺乏高校工作经历, 由学生转变为高 校专业教师的压力较大。 ${ }^{[3]}$ 有些地方政府对高校投入资 金不足, 再加上高校自身平台资源有限等原因, 致使青 年教师引进和培养方面难度较大。 ${ }^{[4]}$ 还有部分高校行政 与学术失衡问题突出, 也加剧了青年教师职称评审的难 度。 ${ }^{[5]}$ 有些高校教师的职业认同感不高, 流动性较大。 青年师资的频繁流动是市场经济环境下常见现象, 特别 是在高校里工作过一定时间, 经过高校培养逐渐成为教 学科研骨干的青年教师的流失, 使得高校师资队伍的稳 定性较差，这对高校的发展极其不利。

究其原因: 第一, 有些高校教师的身份属于聘用制 人员, 与其单位签订聘用劳动合同, 而更多的年轻教师 偏向寻找具有事业编制的岗位。部分教师对高校的未来 发展缺乏信心, 对自身的发展前途普遍感到迷茫, 缺乏 对自己职业的安全感和归属感。第二, 部分教师把高校 的工作当作过渡性职业和跳板。引才不易, 留才更难, 高校在人才的引进和培养上做了很多工作, 但往往是为 人做嫁衣。第三, 有些民办高校的教师在编制身份、养 老保险待遇及社会身份认可度等方面和公办高校教师 相比存在很大的差距, 使许多人才有后顾之忧。由此, 高校在吸引人才、留住人才方面还处于弱势, 高校存在 招聘高端人才、专业精英比较困难的局面, 即便招聘到 或自己培养出优秀的人才, 也面临着较高流失率的困扰。

\section{4. 高校加强师资队伍建设的对策}

\section{1 完善高校师资队伍相关的规章制度}

为了解决以上难题, 鼓励教职工长期、稳定地为高 校工作, 持续为高校发展和学科建设发挥作用, 增强高 校凝聚力, 激发教职工与高校同发展共命运的主人翁精 神, 有些高校出台了《高校终身教授管理办法》《高校 补充养老金实施办法》等系列文件。这些文件的出台, 有效地提高了高校教职工工作的积极性与稳定性, 增强 了高校对外部人才的吸引力度。高校要制定了一系列有 关人才培养项目、在职培训进修、教学能力提升、专业 负责人管理、教师业绩标准、职称评聘、师德建设的规 章制度, 有效地激发了教师的学习工作积极性和动力, 提升了高校教师的职业素养和师德水准, 增强了高校的 核心竞争力。

\section{2加强高校师资干部队伍建设}

用一贤人则群贤毕至，见贤思齐就蔚然成风。选什 么人就是风向标, 就有什么样的干部作风, 乃至就有什 么样的党风。高校未来的发展, 迫切需要一大批既有坚 定信念又敢担当、既有理想又能实干、既干净又干事、 既严于律己又求真务实的好干部。高校坚持党管人才, 继续选优配强各职能部门、二级学院领导班子, 做好干 部的培育、选拔、管理、使用工作。要建立以德为先、 任人唯贤、人事相宜的选拔任用体系, 坚持事业为上, 以事择人、人岗相适。要发挥党员教师的先锋模范作用, 抓好师德师风建设, 严格执行师德 “一票否决制”。秉 承 “育人者先受教育” 的理念, 加强岗前培训, 为新教 师提高师德修养加油助力。注重从优秀青年教师、海外 引进人才和学术带头人中发展党员, 把教师党员培养成 为学术骨干。

\section{3 加强高校师资队伍综合管理}

高校将继续认真学习领会和贯彻落实习近平总书 记重要讲话精神, 以坚持党对教育事业的全面领导, 坚 持把立德树人作为根本任务, 坚持优先发展教育事业, 坚持社会主义办学方向, 坚持扎根中国大地办教育, 坚 持以人民为中心发展教育, 坚持深化教育改革创新, 坚 持把服务中华民族伟大复兴作为教育的重要使命, 坚持 把教师队伍建设作为基础工作为根本遵循, 围绕高校办 学定位、目标与特色服务, 继续开动脑筋、加大人才引 进力度, 加强教职工培训与管理。高校要培养一批高水 平教师，提高师资的综合素质。修订职称评审文件，充 分发挥人才评价的指挥棒作用, 进一步突出教学的重要 地位, 扩大核心成果的范围, 突出品德、能力、业绩导 向, 克服唯论文、唯学历、唯奖项倾向, 激发广大教师 在教学改革、学生指导、学术交流、社会服务等方面的 积极性, 不断改进工作, 满足专业教育不断发展的要求。

总之, 高校要适应新形势, 面对教师发展的新要求, 努力做到因事而化、因时而进、因势而新, 构建新时代 高校师资队伍建设的体系。 ${ }^{[6]}$ 高水平的教师必须具备开 展教学活动的能力及进行学术研究的能力, 同时还应具 备反思、创新、分析, 更要有与同行交流的教学能力。 ${ }^{[7]}$ 高校加强师资队伍建设, 不断提高师资教学水平, 培养 出更多的高水平教师, 从而有利于高校持续发展。

\section{REFERENCES}

[1] Xi, JP.(2018) Xi Jinping stressed at the National Education Congress: adhere to the road of socialist education development with Chinese characteristics and train socialist builders and successors with all-round development of morality, intelligence, body, beauty and labor. People's Daily.9-11.

[2] Wang, HX. (2017) Lack and Reconstruction of 
Teacher's Ideal of Life. Teacher education research.29:16.

[3] Huang, HT, Ge, X. (2017) Current Situation and Policy Suggestions on the Professional Development Needs of New Teachers in Colleges and Universities. Higher Education in Jiangsu.9:59-63.

[4] Li, XY, Li, YJ. (2020) The Development Dilemma of Young Teachers in Provincial Colleges and Universities under the Background of "Double First-class" Construction. Journal of Gannan Normal University.1:48.

[5] Fan, XR, Dai, CL, An, JQ. (2014) Simplifying Administration and Decentralization: The Bottleneck of Deepening the Reform of Employment Mechanism in Colleges and Universities. China Education News.4-28.

[6] Shi, YX. (2019) Basic Experience and Future Prospect of the Construction of Ideological and Political Theory Course in Colleges and Universities in New China. Ideological and theoretical education.9:11.

[7] Cao, YX, Zhang, BW. (2016) Research on Cultivation of Teaching Ability of College Teachers. Journal of Northeast Normal University.2:208-213. 